\title{
Species-specific responses of a cyanobacteria- dominated phytoplankton community to artificial nutrient limitation in the Baltic Sea
}

\author{
Kersti Kangro ${ }^{1}$, Kalle Olli $^{1, *}{ }^{*}$, Timo Tamminen ${ }^{2}$, Risto Lignell ${ }^{3}$ \\ ${ }^{1}$ Institute of Botany and Ecology, Tartu University, Lai 40, Tartu 51005, Estonia \\ ${ }^{2}$ Finnish Environment Institute, PO Box 140, 00251 Helsinki, Finland \\ ${ }^{3}$ Finnish Institute of Marine Research, PO Box 2, 00561 Helsinki, Finland
}

\begin{abstract}
In a 3 wk Baltic Sea coastal experiment artificial $N$ and P limitation were studied in 9 mesocosms, $51 \mathrm{~m}^{3}$ each, filled with a natural summer plankton community. The initial situation (molar dissolved N:P ratio of 0.9 ; zooplankton to phytoplankton biomass ratio of 2.8) was boosted with 5 daily $\mathrm{N}$ and $\mathrm{P}$ additions in Redfield ratio, to increase algal biomass and demand for nutrients. Thereafter, either $\mathrm{N}$ or P limitation was induced by cutting one element, while supplying the other. Discontinuing $\mathrm{N}$ supply resulted in lower phytoplankton biomass (as chlorophyll $a$ and wet weight), but more bloom-forming, $\mathrm{N}_{2}$-fixing filamentous cyanobacteria. Stable C:N and N:P ratios of organic particles and the increase of total nitrogen indicated an average $\mathrm{N}_{2}$-fixation rate of 3.3 to $7.4 \mathrm{mmol} \mathrm{N} \mathrm{m} \mathrm{m} \mathrm{d}^{-1}$, which by the end of the experiment equalised the total $\mathrm{N}$ in the mesocosms with and without $\mathrm{N}$ addition. Discontinuing P supply resulted in higher algal biomass, and the particulate organic matter with increasing molar C:P (from 90 to 300 ) and N:P ratios (from 16 to 50) suggested bulk level P shortage. The biomass response distinguished 3 groups of phytoplankton, each containing filamentous cyanobacterial species that are considered: (1) nitrogen limited, e.g. chlorophytes, non-heterocystous filamentous cyanobacteria Pseudanabaena spp. and colonial cyanobacteria (e.g. Snowella sp., Cyanodictyon sp.); (2) phosphorus limited, e.g. the $\mathrm{N}_{2}$-fixers Anabaena spp. and Nodularia spumigena; and (3) indifferent species, e.g. the $\mathrm{N}_{2}$-fixer Aphanizomenon sp. and heterotrophic and opportunistic flagellates. Aphanizomenon sp. - the dominant species in the experiment-increased equally in all mesocosms at the expense of fixed $\mathrm{N}$ and internal P reserves. Our results highlight the diverse nutritional and growth strategies of the bloom-forming cyanobacteria and suggest that eutrophication management decisions in the Baltic Sea should inevitably consider simultaneous reduction of both $\mathrm{N}$ and $\mathrm{P}$.
\end{abstract}

KEY WORDS: Anabaena $\cdot$ Aphanizomenon $\cdot$ Nodularia $\cdot$ Baltic Sea $\cdot$ Cyanobacteria $\cdot$ Nitrogen fixation $\cdot$ Nutrient limitation $\cdot$ Phytoplankton

\section{INTRODUCTION}

The Baltic Sea - the largest brackish water body in the world - is endangered by large nutrient inputs from the highly populated (ca. 80 million people) drainage area (Elmgren 2001). Massive summer accumulations of $\mathrm{N}_{2}$-fixing filamentous cyanobacteria lower the water quality and recreational value of the
Baltic Sea (Larsson et al. 1985, Elmgren \& Larsson 2001a). Blooms of filamentous cyanobacteria have occurred in the Baltic Sea since the former freshwater Ancylus Lake turned into the brackish Litorina Sea, approximately $7000 \mathrm{yr} \mathrm{BP}$; this was supposedly favoured by the advent of nitrogen limitation in tandem with oxygen depletion in deep water and release of phosphorus from the sediments (Elmgren 2001). 
Lately, the blooms seem to have become more frequent and intense (Kahru et al. 1994, Finni et al. 2001), following an increase of phosphorus and nitrogen inputs by factors of at least 8 and 4 during the last century, respectively (Larsson et al. 1985). The molar N:P ratio of the external total nutrient load is almost 50, well above the Redfield N:P ratio of 16 (Stålnacke et al. 1999), suggesting $P$ limitation in the Baltic Sea. However, recalcitrant dissolved organic $\mathrm{N}$ accounts for a large share of this massive excess total N (Jørgensen et al. 1999). Moreover, denitrification, enhanced by frequent low-oxygen conditions in the deep water, effectively counteracts N inputs (Larsson et al. 1985, Rönner 1985, Tuominen et al. 1998).

The trophic state of the Gulf of Finland (GOF) showed an increasing trend until the 1990s, manifested mainly as a strengthening of the vernal blooms. In the 1990s the trend levelled out, due to decreased availability of $\mathrm{N}$ suppressing the magnitude of vernal blooms, which, however, increased the P reserves for the summer (Raateoja et al. 2005). During the 1990s the total inputs of $\mathrm{N}$ and $\mathrm{P}$ to the GOF from the surrounding countries decreased by 37 and $33 \%$, respectively (Pitkänen et al. 2001), with little change in the N:P input ratio. Despite the decrease in anthropogenic loading, the inorganic P levels in the GOF increased during the 1990s, fuelled by an accelerated internal loading from the large $\mathrm{P}$ reserves in the sediments (Pitkänen et al. 2001). The spreading of anoxia in the deep water enhanced benthic P release, which on an annual scale is suggested to exceed the anthropogenic load by several fold (Lehtoranta et al. 1997, Pitkänen et al. 2003). The recent increase in cyanobacterial blooms is largely attributed to the increased surplus of $\mathrm{P}$ after the vernal exhaustion of $N$, ensuing from an increased proportion of $\mathrm{P}$ not used during the spring, from the increased input to the euphotic layer during the summer, or both (Kahru et al. 2000, Raateoja et al. 2005).

Identification of the growth-limiting nutrient and the response of the phytoplankton community to $\mathrm{N}$ or $\mathrm{P}$ limitation in the Baltic Sea are still under scrutiny (Elmgren \& Larsson 2001b, Larsson et al. 2001). The low phosphate levels common during summer blooms of $\mathrm{N}_{2}$-fixing cyanobacteria, as well as phosphate-addition experiments, suggest that summer production is sometimes P limited, even when the spring bloom is clearly N limited (Granéli et al. 1990, Larsson et al. 2001). Some studies indicate, however, that even when $\mathrm{N}_{2}$-fixers with their internal $\mathrm{N}$ source are P limited, other phytoplankton may remain $\mathrm{N}$ limited (Kivi et al. 1993, Seppälä et al. 1999).

Nodularia spumigena Mertens and Aphanizomenon sp. are the main bloom-forming, $\mathrm{N}_{2}$-fixing cyanobacteria in the open Baltic Sea (Larsson et al. 2001, Wasmund et al. 2001). Several commonly occurring cyanobacteria (N. spumigena, Anabaena spp., Microcystis spp.) may produce toxins and pose health risks for humans and livestock (Luckas et al. 2005). Aphanizomenon flos-aquae (L.) Ralfs, found in lakes around the Baltic Sea, has often been confirmed to be toxic (Willén \& Mattsson 1997), whereas Aphanizomenon isolates from the Baltic Sea have not (Lehtimäki et al. 1997), even though there are no consistent morphological differences between the 2 (Laamanen et al. 2002).

The biomass response of phytoplankton functional groups to changes in nutrient load and nutrient ratios is important, not only scientifically, but also for decision making in eutrophication management. Consensus prevails that the $\mathrm{N}_{2}$-fixing cyanobacteria are favoured by the high or elevated P levels and the low inorganic N:P ratios (Kahru et al. 2000, Rydin et al. 2002), usually well below the Redfield value, as found in the Baltic proper and the GOF in July and August (Granéli et al. 1990). The fact that the most conspicuous Baltic cyanobacterial blooms occur offshore and only for a limited period of the growth season (Kahru et al. 1994, Larsson et al. 2001) complicates management decisions on land-borne nutrient sources. On a local scale, overall phototrophic biomass level and eutrophication are often related to $\mathrm{N}$ loading, and, on an annual scale, the interplay of basin-wide $\mathrm{N}$ and $\mathrm{P}$ cycles may lead to seasonal limitation shifts.

To test different limitation scenarios, coastal mesocosm experiments with a natural plankton community can be designed to provide a good balance between close-to-natural conditions and manipulative control over the system. The aim of the present study was to examine the response of phytoplankton biomass and functional groups (with a focus on filamentous cyanobacteria) to changes in the external nutrient supply rate and to limitation of either $\mathrm{N}$ or $\mathrm{P}$. The study area is generally nitrogen limited in summer (Kivi et al. 1993, Lignell et al. 2003), and we expected nitrogen addition (or combined $\mathrm{N}$ and $\mathrm{P}$ addition) to trigger the strongest overall phytoplankton biomass response. We hypothesised that $\mathrm{N}$ and $\mathrm{P}$ limitation would lead to the dominance of different phytoplankton functional groups.

\section{MATERIALS AND METHODS}

Experimental set-up. The mesocosm experiment was carried out from 1 to 22 July 2003, in a sheltered archipelago site near the Tvärminne Zoological Station (University of Helsinki, Finland; Fig. 1). A natural water column was enclosed in 9 transparent plastic enclosures (polyethylene with glass-fibre reinforcement), with a total volume of $51 \mathrm{~m}^{3}$ each $(2.3 \mathrm{~m}$ diameter; $12 \mathrm{~m}$ deep in main cylindrical part and $2 \mathrm{~m}$ deep in conical bottom part). The enclosures were loosely 


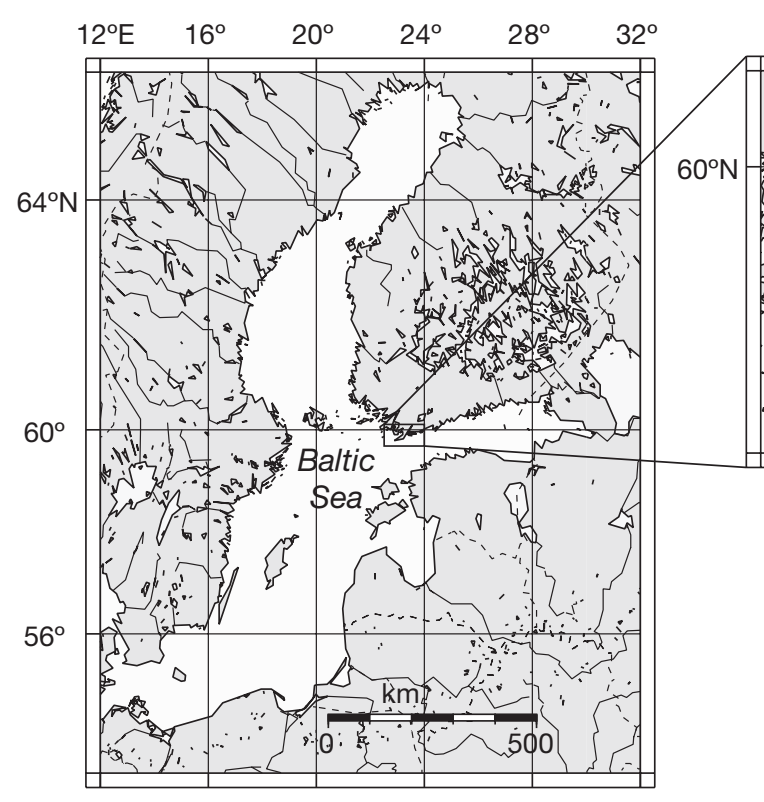

covered with polyethylene lids to allow air exchange, but to prevent contamination by sea birds and atmospheric wet deposition of nutrients.

The mesocosms received evenly distributed mineral nutrients ( $\mathrm{N}$ : ammonium chloride; P: potassium dihydrogen phosphate) to stimulate algal production, and a labile organic carbon source (G: glucose) to increase phytoplankton nutrient limitation through competition by heterotrophic bacteria. An even distribution of these nutrients within the 0 to $12 \mathrm{~m}$ water column was achieved by lowering an open-ended hose into the mesocosm, filling it with the nutrient mixture (diluted into a fixed volume that filled the entire hose), and slowly lifting the hose to the surface with a circular motion. Our earlier experience with similar mesocosm designs and experiment durations (Lignell \& Lindqvist 1992, Kuuppo-Leinikki et al. 1994, Olli \& Seppälä

Table 1. Design of the mesocosm experiment. Nutrient supply rates to the enclosures for $\mathrm{N}$ : $1 \mu \mathrm{mol} \mathrm{NH}_{4}-\mathrm{N} \mathrm{l}^{-1} \mathrm{~d}^{-1}$; $\mathrm{P}: 1 / 16$ $\mu \mathrm{mol} \mathrm{PO}_{4}-\mathrm{P} \mathrm{l}^{-1} \mathrm{~d}^{-1}$; and G: $13.3 \mu \mathrm{mol}$ glucose- $\mathrm{Cl}^{-1} \mathrm{~d}^{-1} .5 \times \mathrm{N}$ and $5 \times \mathrm{P}$ correspond to 5 times this amount of $\mathrm{N}$ and $\mathrm{P}$, respectively

\begin{tabular}{|lcc|}
\hline Mesocosm unit & Days 1-5 & Days 6-20 \\
\hline $1 \mathrm{NP}$ & $\mathrm{N}+\mathrm{P}$ & $\mathrm{N}+\mathrm{P}$ \\
$2 \mathrm{~N}$ & $\mathrm{~N}+\mathrm{P}$ & $\mathrm{N}$ \\
$3 \mathrm{P}$ & $\mathrm{N}+\mathrm{P}$ & $\mathrm{P}$ \\
$45 \mathrm{~N}$ & $\mathrm{~N}+\mathrm{P}$ & $5 \times \mathrm{N}$ \\
$55 \mathrm{P}$ & $\mathrm{N}+\mathrm{P}$ & $5 \times \mathrm{P}$ \\
$65 \mathrm{NG}$ & $\mathrm{N}+\mathrm{P}$ & $5 \times \mathrm{N}+\mathrm{G}$ \\
$75 \mathrm{PG}$ & $\mathrm{N}+\mathrm{P}$ & $5 \times \mathrm{P}+\mathrm{G}$ \\
8 NPG & $\mathrm{N}+\mathrm{P}$ & $\mathrm{N}+\mathrm{P}+\mathrm{G}$ \\
$9 \mathrm{C}$ & $\mathrm{None}$ & None \\
\hline
\end{tabular}

Fig. 1. Location of the study site
2001, Olli 2004) assured that no significant wall growth would occur. Eight mesocosms received the same amounts of nutrients during the first $5 \mathrm{~d}$ (the boosting period). From then on, external nutrient supply rates diverged (Table 1). Increasing severity on P limitation was expected in $\mathrm{N}<5 \mathrm{~N}<5 \mathrm{NG}$, and $\mathrm{N}$ limitation in $\mathrm{P}<$ $5 \mathrm{P}<5 \mathrm{PG}$ mesocosms, while NP and NPG received nutrients in Redfield ratio (16:1 mol:mol). The control enclosure did not receive any nutrients throughout the experiment ( $\mathrm{C}$ unit). There were no true replicates in the experiment, but the design was factorial. Earlier, similar experiments had shown that the variance in the abundance of individual phytoplankton species between replicate mesocosms was $<10 \%$ (Olli et al. 1996).

Sampling and sample analysis. Discrete water column samples from 0 to $7 \mathrm{~m}$ were taken at $1 \mathrm{~m}$ depth intervals with a 51 volume Limnos type cylindrical tube sampler and pooled thereafter into 1 composite sample. All sampling was done in the morning (local time 07:00 to $08: 00 \mathrm{~h})$ prior to the daily enrichments $(10: 00$ to $11: 00 \mathrm{~h})$. Aliquots for phytoplankton and ciliate counts (250 ml, Lugol preserved, analysed with Leica DM IL inverted microscope), particulate organic carbon (POC), nitrogen (PON) and phosphorus (POP) and total nitrogen were taken on odd days. Phytoplankton wet weight was estimated from biovolume by approximating the cell shape to the closest geometric form and applying a density of 1 . The length of cyanobacterial filaments on fixed width transects over the phytoplankton settling chamber was recorded for each species. Nodularia, Aphanizomenon and Pseudanabaena were treated as cylinders. For Anabaena spp. the mean cell number per unit filament length was calculated, 
and the cells were treated as spheres. For irregularsized colonial cyanobacteria (Aphanocapsa spp., Cyanodictyon spp., Coelosphaerium spp.) the diameter of the colony, approximated to a spherical shape, was measured and the total cell volume within the colony was estimated. On even days, 81 of bottom water was pumped out using a hand pump connected to the lower conical part of the enclosures with a $14 \mathrm{~m}$ long tube, and was analysed for settled PON. Aliquots for dissolved mineral nutrients $\left(\mathrm{NO}_{2}-\mathrm{N}+\mathrm{NO}_{3}-\mathrm{N}_{1} \mathrm{PO}_{4}-\right.$ $\left.\mathrm{P}, \mathrm{NH}_{4}-\mathrm{N}, \mathrm{SiO}_{4}\right)$ and chlorophyll a (chl a) were taken daily. Nutrients were analysed according to Grasshoff et al. (1983) and chl a fluorometrically (Shimadzu RF 5001) after dark extraction in $94 \%$ ethanol. Samples for particulate organic nutrients (POC, PON, POP) were filtered onto acid-washed and pre-combusted $(4 \mathrm{~h}$ at $500^{\circ} \mathrm{C}$ ) Whatman GF/F filters. POC and PON filters were dried at room temperature and analysed with a mass spectrometer (Europa Scientific). POP was analysed according to Solorzano \& Sharp (1980). Total nitrogen was measured colorimetrically after wet oxidation to nitrate (Grasshoff et al. 1983). Mesozooplankton was sampled by pouring 201 of pooled water ( 0 to $7 \mathrm{~m}$ ) through $48 \mu \mathrm{m}$ mesh every 4 th day. The $250 \mathrm{ml}$ concentrated sample was fixed with Lugol's solution and counted with a dissecting microscope.

During water column sampling, temperature was measured manually (with a thermometer connected to the sampler) at $3 \mathrm{~m}$ depth. Underwater light profiles were measured from 1 to $6 \mathrm{~m}$ depth (1 m intervals) around local noon (surface irradiance 1400 to $1700 \mu \mathrm{mol} \mathrm{m}^{-2} \mathrm{~s}^{-1}$ ) from $5 \mathrm{~N}$ and $5 \mathrm{P}$ mesocosms on Days 8,14 and 18 with a Li-Cor scalar underwater sensor, normalised with a reference cosine surface sensor.

Data analysis. We used Canoco 4.5 (Biometris-Plant Research International) for analysing the relationship between phytoplankton community and environmental factors. The analysis included 72 samples, 66 phytoplankton taxa (after exclusion of rare taxa) and 11 environmental factors ( $\mathrm{N}, \mathrm{P}$ and $\mathrm{C}$ additions, residual mineral DIN:DIP ratio, temperature, biomasses of cladocerans, copepods, naupliae, ciliates and main groups of rotifers). Prior to the main data analysis, heterogeneity in the phytoplankton species community was estimated by detrended correspondence analysis (DCA). According to DCA the community was homogeneous enough (the length of the gradient in species biomass was $\sim 2.05$ ) to justify linear ordination methods.

We used a constrained ordination approach to find the variability in phytoplankton species composition that can be explained by environmental variables. Redundancy analysis (RDA) is often used in ecology for ordination by direct gradient analysis, where a matrix of species is analysed with regard to a corre- sponding matrix of environmental variables. RDA was used to test the main effects of nutrient additions on the whole phytoplankton community. Species data in ordination analysis were standardised prior to analysis, in order to down-weight the effect of dominant species (gives equal weight to species). However, standardisation caused only minor differences in the results compared to non-standardised data. Time effects were removed by using time as a covariable in the analysis. The phytoplankton species with the largest divergence between the treatments are shown in the species-environment biplot-an illustration from the redundancy analysis (see Fig. 3). To test the significance of explained variability, we used Monte-Carlo permutations (499 simulations, restricted to treatments). In parallel we screened the identified taxa for their preference for $\mathrm{N}$ or $\mathrm{P}$ addition. Biomasses from units with $\mathrm{N}(\mathrm{N}, 5 \mathrm{~N}, 5 \mathrm{NG})$ and $\mathrm{P}(\mathrm{P}, 5 \mathrm{P}, 5 \mathrm{PG})$ additions were tested for equality of median with Wilcoxon 2-sided rank sum test. We used principal component analysis (PCA) to test differences in phyto- and zooplankton community composition between mesocosms receiving $\mathrm{N}$ and $\mathrm{P}$ treatments.

We expected the plankton community to be similar between the mesocosms during the boosting period and the early phase of differential treatments. Thus, in the statistical analyses (Wilcoxon rank sum tests, PCA, RDA), data from Experimental Day 11 onwards were used.

\section{RESULTS}

\section{Physical and chemical environment}

Following an onset of high pressure, the surface water temperature increased from $15.3^{\circ} \mathrm{C}$ at the beginning of the experiment to $17.8^{\circ} \mathrm{C}$ during the first week, and reached 19 to $22^{\circ} \mathrm{C}$ during the third week. The temperatures inside and outside the mesocosms were very similar, as in previous experiments with such enclosures (Olli et al. 1996). Underwater light attenuation coefficients increased from initially $0.33 \mathrm{~m}^{-1}$ to $0.43-0.47 \mathrm{~m}^{-1}$ (Days 8 and 14) and further to $0.67-0.70 \mathrm{~m}^{-1}$ (Day 18). This corresponded to a decrease in the euphotic layer depth $(1 \%$ surface irradiance, ca. $15 \mu \mathrm{mol} \mathrm{m}{ }^{-2} \mathrm{~s}^{-1}$ ) from 14 to $10 \mathrm{~m}$ and further to $7 \mathrm{~m}$. There were no consistent differences in light attenuation between the $5 \mathrm{~N}$ and $5 \mathrm{P}$ mesocosms. Salinity in the mesocosms ranged from 5.75 to 5.82. Nitrate plus nitrite concentration, which initially averaged $0.09 \mu \mathrm{mol} \mathrm{l}^{-1}$ (range 0.08 to $\left.0.12 \mu \mathrm{mol} \mathrm{l}^{-1}\right)$, varied between 0.2 and $0.3 \mu \mathrm{mol} \mathrm{l}^{-1}$ during most of the experiment. 
After the boosting period, ammonium and phosphate concentrations (initially 0.1 and $0.2 \mu \mathrm{mol} \mathrm{\textrm {l } ^ { - 1 }}$, respectively) reflected the experimental design. Ammonium remained $<0.3 \mu \mathrm{mol} \mathrm{l}^{-1}$ in all mesocosms, except in the $5 \mathrm{~N}$ and $5 \mathrm{NG}$ units, where it accumulated $\left(>5 \mu \mathrm{mol}^{-1}\right)$. Phosphate remained $<0.1 \mu \mathrm{mol} \mathrm{l}^{-1}$, except in $\mathrm{P}(0.2$ to $0.5 \mu \mathrm{mol} \mathrm{l}^{-1}$ ), and the 5P and 5PG units (both generally $>1 \mu \mathrm{mol} \mathrm{l}^{-1}$ ) (Table 2). The mineral dissolved N:P ratio (initially 0.9 ) ranged from 0.5 to 0.7 (5P, 5PG units) to $>100$ (5N and 5NG units) after the boosting period (Table 2).

The molar POC:PON ratio remained close to the Redfield ratio (6.6) after the nutrient additions, with no clear differences between the treatments (Table 2). The PON:POP ratio (initially $13.1 \pm 0.7$ ) remained close to the Redfield ratio (16) in mesocosms with excess phosphorus addition (12 to 19, mean 14 in $\mathrm{P}, 5 \mathrm{P}, 5 \mathrm{PG}$ units), but increased to $>30$ in mesocosms with excess $\mathrm{N}$ addition ( $\mathrm{N}, 5 \mathrm{~N}, 5 \mathrm{NG}$ ) (Table 2 ). The POC:POP ratio decreased from initially $115( \pm 7)$ to 100 during the boosting period. In $\mathrm{P}, 5 \mathrm{P}$ and $5 \mathrm{PG}$ units this ratio remained generally between 80 and 100 , but in $N, 5 N$ and 5 NG units it increased to $>200$, reaching 300 in the 5NG unit (Table 2).

Total organic nitrogen (total nitrogen minus the dissolved inorganic species) increased from $22( \pm 0.6)$ to $29( \pm 2) \mu \mathrm{mol} \mathrm{l^{-1 }}$ during the boosting period and thereafter to about $40 \mu \mathrm{mol} \mathrm{l}^{-1}$ by the end of the experiment. In mesocosms without $\mathrm{N}$ addition after the boosting period, total organic nitrogen still increased, lagging behind units with $\mathrm{N}$ addition by about $10 \%$, but this difference disappeared by the end of the experiment, and in the 5P unit the total organic nitrogen even exceeded the respective concentration in the $5 \mathrm{~N}$ unit. In the control unit, total organic nitrogen lagged behind at ca. $60 \%$ of the average concentration in nutrient-enriched mesocosms ( $\mathrm{N}$ and $\mathrm{NP}$ ), but from Day 15 onwards the difference decreased, finally reaching $90 \%$ of the mean of enriched mesocosms.

The sedimentation loss of PON from the system was negligible $\left(<0.1 \mathrm{mmol} \mathrm{N} \mathrm{m}^{-2} \mathrm{~d}^{-1}\right)$ throughout the first $10 \mathrm{~d}$ of the experiment in all the mesocosms, followed by a sedimentation event ( 2 to $5, \max .7 \mathrm{mmol} \mathrm{N} \mathrm{m}{ }^{-2}$ $\mathrm{d}^{-1}$ ) between Days 14 and 18. Thereafter, PON sedimentation generally dropped to $<1 \mathrm{mmol} \mathrm{N} \mathrm{m}^{-2} \mathrm{~d}^{-1}$. In the control unit, PON sedimentation remained $<0.3 \mathrm{mmol} \mathrm{N} \mathrm{m}^{-2} \mathrm{~d}^{-1}$ (0.36 on Day 22). Sedimentation was a minor loss of PON from the system, comprising typically $<0.1 \% \mathrm{~d}^{-1}$ of the standing stock and 0.3 to $2.5 \% \mathrm{~d}^{-1}$ during peak sedimentation events.

\section{Phyto- and zooplankton}

The chl a-based phototrophic biomass response was most pronounced in the $5 \mathrm{~N}$ and $5 \mathrm{NG}$ units (from the initial $3.5 \pm 0.2$ to $40 \mu \mathrm{g} \mathrm{chl} \mathrm{l}^{-1}$ ). However, the $\mathrm{P}, 5 \mathrm{P}$ and 5PG units, where the biomass remained generally

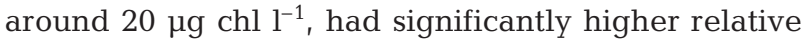
and absolute amounts of the $\mathrm{N}_{2}$-fixing, bloom-forming cyanobacteria Anabaena spp. and Nodularia spumigena (Table 3), but not Aphanizomenon sp. (Table 4). During the boosting period, the phytoplankton wet weight biomass increased from initially $0.35 \pm 0.05$ to $1.2 \pm 0.5 \mathrm{mg} \mathrm{l}^{-1}$ in the nutrient-enriched mesocosms. Thereafter, the biomass increased most in mesocosms with combined additions (NP, NPG; up to $4.6 \mathrm{mg} \mathrm{l}^{-1}$; Fig. 2). Apart from the general agreement, chl $a$ indicated a higher phototrophic biomass in the $5 \mathrm{~N}$ and 5NG units (data not shown) compared to microscopy counts. This may partly be due to counting statistics and bio-volume conversion factors, but was more likely caused by higher cellular chlorophyll content, due to excess availability of nitrogen.

Cyanobacteria became the predominant group in all enclosures, increasing from an initial range of 27-57 to $73-96 \%$ of the total phytoplankton biomass by the end of the experiment. The most important cyanobacterial groups were filamentous diazotrophic, non-heterocystous filamentous species and colonial forms. Diazotrophs were dominated by Aphanizomenon sp., which increased on average 50 -fold from the initial 0.03 to $0.05 \mathrm{mg} \mathrm{l}^{-1}$ (5 to $18 \%$ of the total phytoplankton biomass) to 0.9 to $2.5 \mathrm{mg} \mathrm{l}^{-1}$ (40 to $50 \%$ of the biomass,

Table 2. Mean $\pm \mathrm{SD}$ (Days 11 to 21) of dissolved inorganic nitrogen (DIN $=\mathrm{NO}_{2}+\mathrm{NO}_{3}+\mathrm{NH}_{4} ; \mu$ mol $\mathrm{l}^{-1}$ ) and phosphorus $(\mathrm{DIP}=$ $\mathrm{PO}_{4} ; \mu \mathrm{mol} \mathrm{l} \mathrm{l}^{-1}$ ) concentrations, and molar ratios of dissolved mineral $\mathrm{N}$ and $\mathrm{P}$ (DIN:DIP) and particulate organic nutrients (POC:PON, PON:POP, POC:POP) in the 0 to $7 \mathrm{~m}$ upper layer of the mesocosms

\begin{tabular}{|lcccccc|}
\hline Treatment & $5 \mathrm{~N}, 5 \mathrm{NG}$ & $\mathrm{N}$ & Control & NP, NPG & P & 5P, 5PG \\
\hline DIN & $8.5 \pm 2.9$ & $0.6 \pm 0.5$ & $0.5 \pm 0.2$ & $0.5 \pm 0.2$ & $0.5 \pm 0.1$ & $0.5 \pm 0.1$ \\
DIP & $0.09 \pm 0.03$ & $0.08 \pm 0.02$ & $0.08 \pm 0.02$ & $0.10 \pm 0.03$ & $0.44 \pm 0.13$ & $1.18 \pm 0.50$ \\
DIN:DIP & $111.3 \pm 53.7$ & $8.1 \pm 6.3$ & $6.2 \pm 1.8$ & $5.5 \pm 2.2$ & $1.2 \pm 0.7$ & $0.6 \pm 0.6$ \\
POC:PON & $6.1 \pm 0.6$ & $6.8 \pm 1.2$ & $7.1 \pm 1.3$ & $7.1 \pm 1.0$ & $6.7 \pm 1.1$ & $6.7 \pm 0.7$ \\
PON:POP & $38.2 \pm 8.2$ & $32.6 \pm 9.0$ & $18.7 \pm 5.4$ & $17.3 \pm 2.7$ & $13.9 \pm 2.0$ & $14.2 \pm 2.2$ \\
POC:POP & $233 \pm 54$ & $219 \pm 59$ & $132 \pm 36$ & $121 \pm 22$ & $91 \pm 8$ & $94 \pm 11$ \\
\hline
\end{tabular}


but $75 \%$ in the control unit; Fig. 2). The second most important genus was Anabaena, with at least 7 different taxa, not all of which could be identified to species level. The most abundant was A. lemmermannii Richter, which increased from the initial $12 \mu \mathrm{g}$ $\mathrm{l}^{-1}$ (mean of all enclosures) to a maximum of $900 \mu \mathrm{g} \mathrm{l^{-1 }}$ (in 5PG). Nodularia spumigena increased only during the second half of the experiment, but did not reach high biomass $\left(<100 \mu \mathrm{g} \mathrm{l}^{-1}\right)$. The non-heterocystous filaments were dominated by Pseudanabaena limnetica (Lemmermann) Komárek (mostly <0.5, max. $1 \mathrm{mg} \mathrm{l}^{-1}$ ). The colonial cyanobacteria, Cyanodictyon spp., Aphanocapsa sp., Gomphosphaeria sp., Coelosphaerium sp. and Snowella sp., formed $<50 \%$ of the total

Table 3. Phytoplankton taxa with positive biomass response to excess $\mathrm{N}$ or $\mathrm{P}$ supply rate from Day 11 onwards. Difference between the medians of biomasses in $\mathrm{N}$ enriched $(\mathrm{N}, 5 \mathrm{~N}, 5 \mathrm{NG})$ and $\mathrm{P}$ enriched ( $\mathrm{P}, 5 \mathrm{P}, 5 \mathrm{PG})$ mesocosms were tested with the 2 -sided Wilcoxon rank sum test ( $p$-value). Biomass ratio is the ratio of the mean biomass of the taxon in mesocosms with the favouring nutrient addition over the non-favouring nutrient

\begin{tabular}{|c|c|c|c|}
\hline Taxon & $\mathrm{p}$ & $\begin{array}{l}\text { Biomass } \\
\text { ratio }\end{array}$ & $\begin{array}{c}\text { Favouring } \\
\text { nutrient }\end{array}$ \\
\hline Dictyosphaerium balticum & 0.05 & 4.7 & $\mathrm{~N}$ \\
\hline Dictyosphaerium sp. & 0.01 & 5.1 & $\mathrm{~N}$ \\
\hline Monoraphidium contortum & 0.05 & 1.9 & $\mathrm{~N}$ \\
\hline Oocystis sp. & 0.01 & 3.4 & $\mathrm{~N}$ \\
\hline Pseudopedinella elastica & 0.001 & 4.8 & $\mathrm{~N}$ \\
\hline Pseudanabaena limnetica & 0.001 & 2.8 & $\mathrm{~N}$ \\
\hline Pseudanabaena sp. & 0.005 & 3.8 & $\mathrm{~N}$ \\
\hline Cyanodictyon sp. & 0.005 & 12 & $\mathrm{~N}$ \\
\hline Gomposphaeria compacta & 0.05 & 2.4 & $\mathrm{~N}$ \\
\hline Teleaulax amphioxeia & 0.01 & 12 & $\mathrm{~N}$ \\
\hline Thalassiosira sp. & 0.001 & 9.0 & $\mathrm{~N}$ \\
\hline Anabaena sp. 2 & 0.005 & 42 & $\mathrm{P}$ \\
\hline Anabaena sp. 3 & 0.005 & 2.0 & $\mathrm{P}$ \\
\hline Anabaena lemmermannii & 0.05 & 2.2 & $\mathrm{P}$ \\
\hline Nodularia spumigena & 0.01 & 3.7 & $\mathrm{P}$ \\
\hline Cylindrotheca closterium & 0.01 & 4.8 & $\mathrm{P}$ \\
\hline Dinophysis acuminata & 0.005 & 4.7 & $\mathrm{P}$ \\
\hline Dinobryon faculiferum & 0.05 & 3.1 & $\mathrm{P}$ \\
\hline
\end{tabular}

Table 4. Phytoplankton taxa with neutral biomass response to excess $\mathrm{N}$ or P supply rate from Day 11 onwards; $\mathrm{p}$-value as in Table 3. Ratio of mean biomass in $N$ enriched $(\mathrm{N}, 5 \mathrm{~N}, 5 \mathrm{NG})$ and $\mathrm{P}$ enriched ( $\mathrm{P}, 5 \mathrm{P}, 5 \mathrm{PG})$ mesocosms

\begin{tabular}{|lcc|}
\hline Taxon & $\mathrm{p}$ & Biomass ratio \\
\hline Aphanizomenon sp. & 1 & 0.98 \\
Anabaena cylindrica & 0.64 & 0.70 \\
Dinophysis rotundata & 1 & 1.1 \\
Amphidinium crassum & 0.96 & 2.3 \\
Heterocapsa rotundata & 0.57 & 0.46 \\
Heterocapsa triquetra & 0.45 & 0.91 \\
Apedinella spinifera & 0.46 & 0.81 \\
\hline
\end{tabular}

cyanobacterial biomass, with a combined biomass up to $1 \mathrm{mg} \mathrm{l}^{-1}$.

Changes in nutrient supply rates led to changes in the community composition. After screening the biomass response of the 82 taxa (not all at species level), we distinguished 3 groups of algae. Excess $\mathrm{N}$ favoured non-heterocystous and colonial cyanobacteria and chlorophytes, while the diazotrophs were generally favoured by $\mathrm{P}$ (Table 3). The third group, selected somewhat subjectively (based on relatively similar biomasses under $\mathrm{N}$ and $\mathrm{P}$ addition formalised by a high $\mathrm{p}$-value of the Wilcoxon rank-sum test, a high frequency of occurrence and reliable counting statistics), performed equally well in $\mathrm{N}$ - and P-enriched meso-

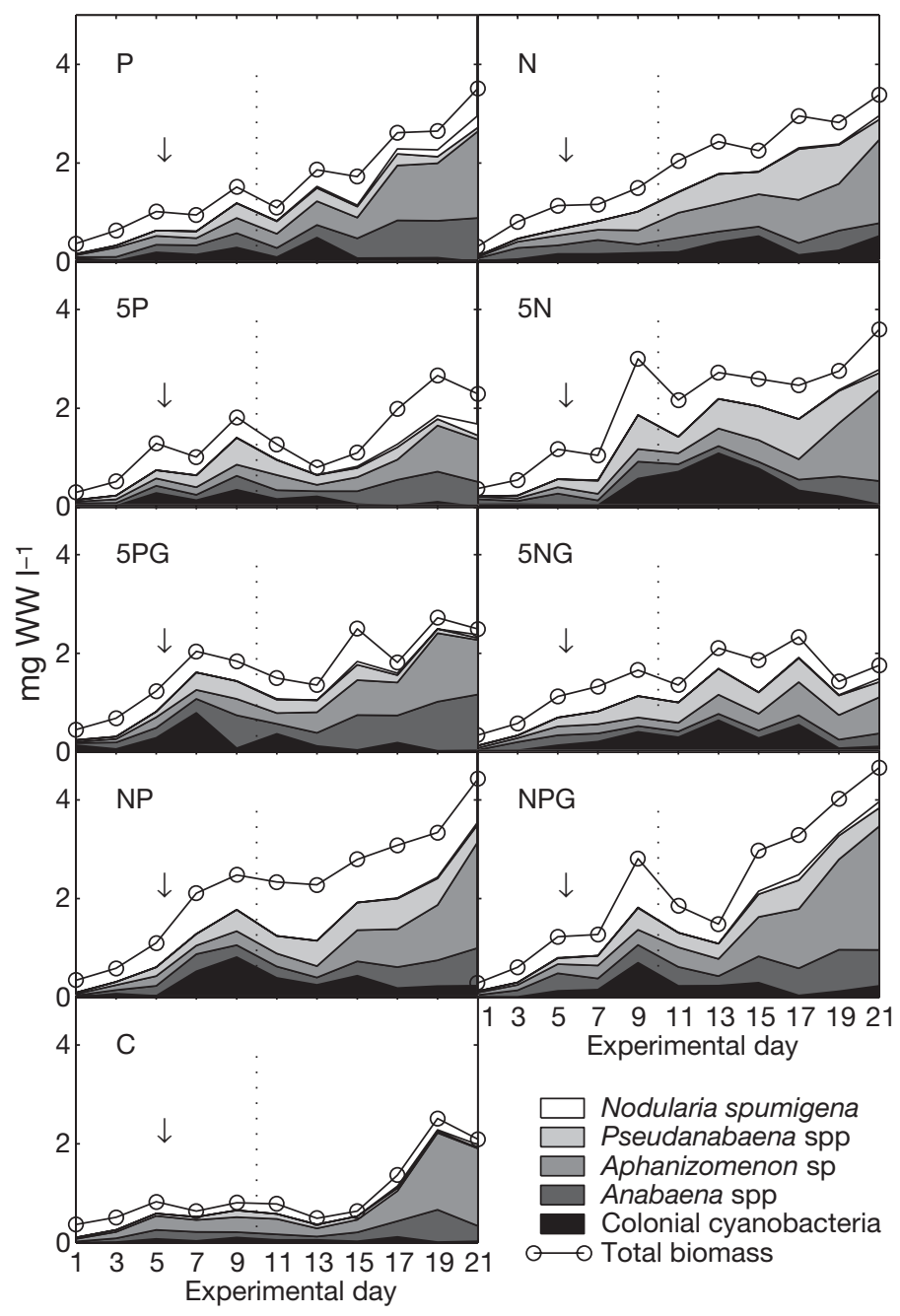

Fig. 2. Biomass of the most important cyanobacterial groups and the total biomass of phytoplankton in wet weight units $\left(\mathrm{mg} \mathrm{WW}^{-1}\right.$ ). Arrows denote the end of the boosting period, and vertical dotted lines, the start of the period for which statistical inferences were made. Colonial cyanobacteria include species of Aphanocapsa, Coelosphaerium, Cyanodictyon, Gomphosphaeria and Snowella 
cosms (Table 4). Somewhat surprisingly, 2 diazotrophic cyanobacteria (Aphanizomenon sp., Anabaena cylindrica Lemmermann) belonged to this group.

The grouping based on direct biomass response agreed well with the results of the redundancy analysis. The species-environmental biplot illustrates the correlation of phytoplankton species with $\mathrm{N}$ and $\mathrm{P}$ additions (Fig. 3). Several flagellates and colonial and filamentous non-heterocystous cyanobacteria were positively correlated with $\mathrm{N}$ addition, whereas Anabaena species and Nodularia spumigena were positively correlated with $\mathrm{P}$ addition. Aphanizomenon sp. was not correlated with any nutrient addition. PCA ordination based on cyanobacterial species composition demonstrated a clear separation of samples from $\mathrm{N}$ and $\mathrm{P}$ treatments (Fig. 4).

Overall the environmental factors explained $30 \%$ of the phytoplankton compositional variability $(\mathrm{p}>0.05)$. Temperature explained $2 \%$ of the variability in the species composition $(p>0.05)$. Despite the small effect on the overall community composition, temperature correlated positively (Spearman rank correlation, $\mathrm{r}>$ 0.75, $\mathrm{p}<0.01$ ) with the biomass of Aphanizomenon sp. and Anabaena spp. Nitrogen and phosphorus additions were both significant, each describing about $6 \%$ of the variation in the community composition.

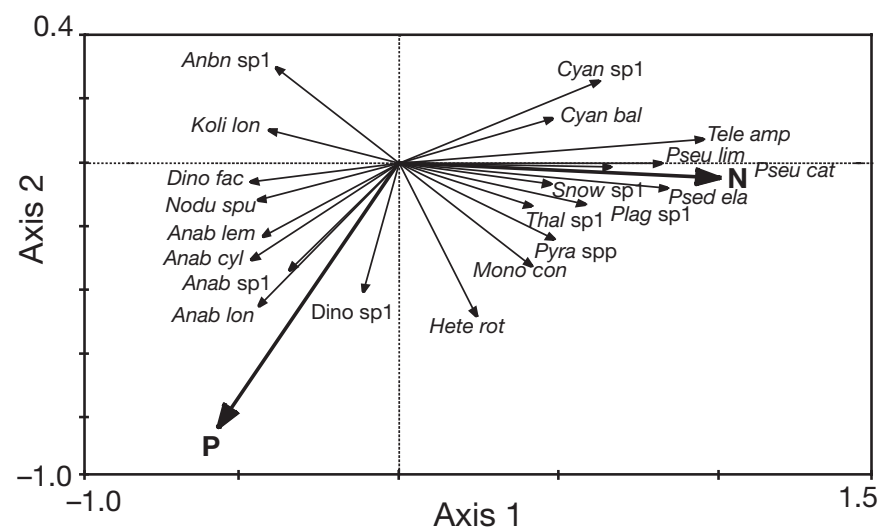

Fig. 3. Species-environmental biplot showing the response of phytoplankton taxa to the nitrogen and phosphorus additions. Phytoplankton biomass data are centred and standardised. Only species with a goodness of fit $>5 \%$ are shown in the ordination space. The arrows of taxa and environmental variables point in the direction of the steepest increase of the respective variable (Anab cyl: Anabaena cylindrica; Anab lem: Anabaena lemmermannii; Anab lon: Anabaena longicellularis; Anab sp1: Anabaena sp. 1; Anbn sp1: Anabaenopsis sp. 1; Cyan bal: Cyanodictyon balticum; Cyan sp1: Cyanodictyon sp. 1; Dino fac: Dinobryon faculiferum; Dino sp1: dinoflagellate sp. 1; Hete rot: Heterocapsa rotundata; Koli lon: Koliella longiseta; Mono con: Monoraphidium contortum; Nodu spu: Nodularia spumigena; Plag sp1: Plagioselmis sp. 1; Psed ela: Pseudopedinella elastica; Pseu cat: Pseudanabaena Catenata; Pseu lim: Pseudanabaena limnetica; Pyra spp.: Pyramimonas spp.; Snow sp1: Snowella sp. 1; Tele amp: Teleaulax amphioxeia; Thal sp1: Thalassiosira sp. 1)
The mesozooplankton showed pronounced temporal dynamics in the mesocosms, with initially very high biomass in relation to autotrophic biomass (2.8-fold). The boosting period evidenced a rise and decline of the rotifers Synchaeta spp. (max. $3.0 \mathrm{mg} \mathrm{l}^{-1}$; up to $95 \%$ of zooplankton biomass), followed by cladocerans (mainly Pleopsis polyphemoides Leuckart) in the midphase of the experiment (Fig. 5). After the decline of cladocerans another rotifer genus, Keratella, increased towards the end of the experiment (up to $2.2 \mathrm{mg} \mathrm{l}^{-1}$ ). The response of copepods to the increased food availability was slow but steady (Fig. 5). Copepod biomass (mostly Eurytemora affinis Poppe and Acartia bifilosa Giesbrecht) increased up to $0.9 \mathrm{mg} \mathrm{l}^{-1}$ by the end of the experiment. Despite the pronounced temporal sequence, zooplankton species composition and total biomass were relatively similar between treatments, as

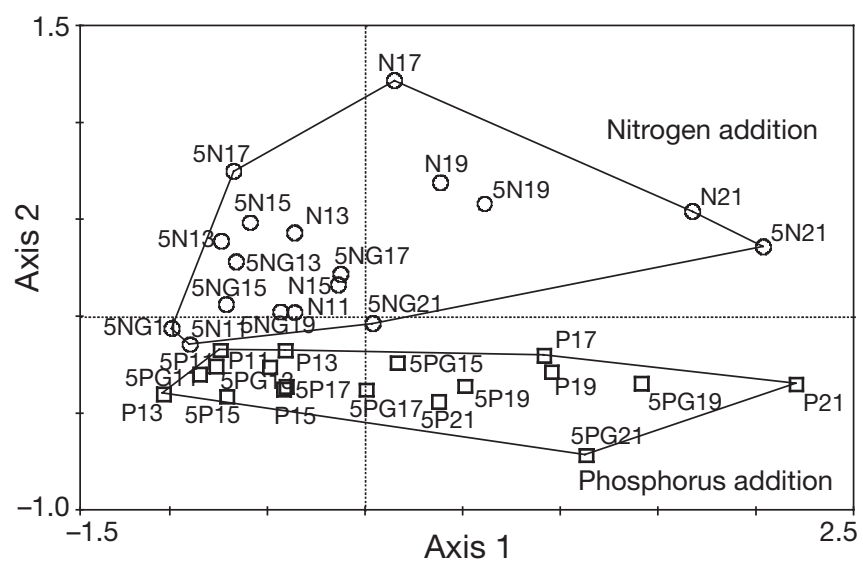

Fig. 4. PCA ordination of samples (Day 11 onwards) based on the 22 most important cyanobacterial taxa. Samples are labelled by mesocosm code (Table 1) followed by 2 digit experimental day. Sample grouping is based on $\mathrm{N}$ or P addition. First 2 axes explain 25 and $13 \%$ of the variability in the species community, respectively

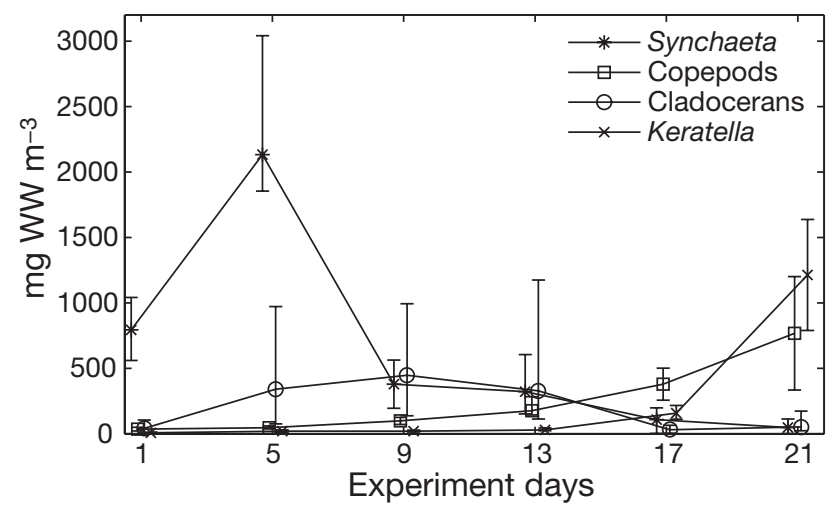

Fig. 5. Average ( $\pm \mathrm{SD}$ ) biomass dynamics (wet weight, WW) of the main mesozooplankton groups in the mesocosms 


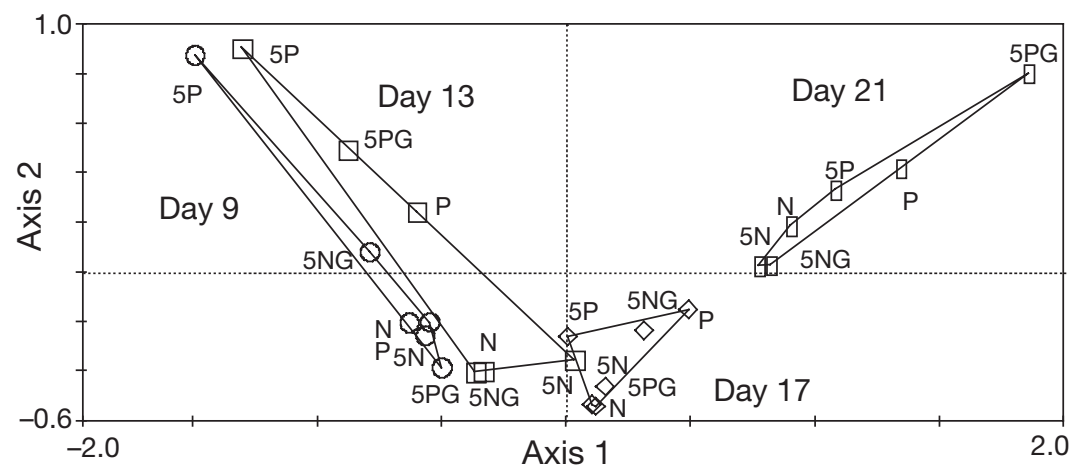

Fig. 6. PCA ordination of samples based on zooplankton data (Day 11 onwards). Sample grouping is based on experimental day. First 2 axes explain 67 and $23 \%$ of the variability in zooplankton data, respectively

is evident from the PCA analysis of the zooplankton data (Fig. 6), which revealed clear grouping of the samples according to time, irrespective of the treatments. Overall, zooplankton had only a minor effect on the phytoplankton compositional differences between treatments. All zooplankton groups (copepods, cladocerans, naupliae, Synchaeta spp., Keratella spp.) and ciliates explained $10 \%$ of the variability in phytoplankton community composition ( $p>0.05)$.

\section{DISCUSSION}

\section{Nitrogen fixation in the balance of mesocosms}

Our study demonstrates that changes in the N:P ratio of the nutrient supply can have an immediate effect (time scale of a wk) on phytoplankton biomass and species composition in the coastal Baltic Sea. Selectively cutting the $\mathrm{N}$ supply resulted in lower overall phytoplankton biomass, but the absolute and, even more, the relative amount of bloom-forming filamentous cyanobacteria was higher. However, the responses of the phytoplankton species, even within the diazotrophic group, were highly species specific.

Excess nitrogen, or combined $\mathrm{N}$ and $\mathrm{P}$ addition, caused higher biomass and chlorophyll levels, which is in line with the perception of the nitrogen limitation of the phytoplankton at a community level in the GOF during summer (Kivi et al. 1993, Lignell et al. 2003) and underlines the importance of nitrogen reduction to combat the effects of eutrophication. However, the total biomass and competitive ability of $\mathrm{N}_{2}$-fixing, bloom-forming cyanobacteria was lower with excess nitrogen addition, with the notable exception of Aphanizomenon sp. This fits the general paradigm that low $\mathrm{N}: \mathrm{P}$ supply ratio favours diazotrophic cyanobacteria, which can satisfy their need for nitrogen with gaseous
$\mathrm{N}_{2}$ (Larsson et al. 2001, Rydin et al. 2002, Ferber et al. 2004).

The relatively stable PON:POP ratios close to the Redfield ratio in the mesocosms with excess phosphorus and no nitrogen addition suggest that extreme nitrogen limitation was avoided at the bulk level-presumably through nitrogen fixation in the highly cyanobacteria-dominated communities. We can indirectly estimate the amount of nitrogen fixed in the Penriched mesocosms. Assuming that no new nitrogen, apart from cyanobacterial fixation, entered the system in $\mathrm{P}, 5 \mathrm{P}$ and 5PG enclosures after the boosting period and in the $\mathrm{C}$ enclosure right after the start of the experiment, we can approximate the nitrogen fixation rate by the increase of total nitrogen in the water column plus the PON removed through sedimentation.

These calculations yield an average nitrogen fixation rate of 3.3 to $5.0 \mathrm{mmol} \mathrm{N} \mathrm{m}^{-2} \mathrm{~d}^{-1}$ in $\mathrm{P}$ and $5 \mathrm{P}$ enclosures after the boosting period and $7.4 \mathrm{mmol} \mathrm{N} \mathrm{m}^{-2} \mathrm{~d}^{-1}$ in the control enclosure throughout the experiment. These average estimates are in the range of nitrogen fixation rates between 2.3 and $5.9 \mathrm{mmol} \mathrm{N} \mathrm{m}^{-2} \mathrm{~d}^{-1}$ calculated by Larsson et al. (2001) for the strongly Aphanizomenon-dominated offshore waters of the Baltic proper and 0.8 to $11 \mathrm{mmol} \mathrm{N} \mathrm{m} \mathrm{N}^{-2} \mathrm{~d}^{-1}$ determined by Wasmund et al. (2001) for the eastern Gotland basin in July and August. Our mean estimates for the whole period after boosting do not reflect escalation of nitrogen fixation during the last $5 \mathrm{~d}$, with rates in the range of 10 to $17 \mathrm{mmol} \mathrm{N} \mathrm{m}^{-2} \mathrm{~d}^{-1}$ (up to 21 in the $\mathrm{C}$ unit).

\section{Competition between $\mathrm{N}_{2}$-fixing cyanobacterial species}

Somewhat unexpectedly, one of the main nuisance, high-biomass species in the Baltic Sea, Aphanizomenon sp., increased almost equally in all the mesocosms, including the control, and revealed no yield differences between the nitrogen- and phosphorus-enriched enclosures. This biomass increase was also reflected in the biogeochemistry, as Aphanizomenon was a major component of the phototrophic compartment and, depending on the phosphorus availability, can apparently have highly variable intracellular N:P and C:P ratios. The bulk POC:POP ratio in the $\mathrm{N}, 5 \mathrm{~N}$ and 5NG enclosures departed rapidly from the Redfield ratio (106C:16N:1P) after Day 9, increasing to a range of 250 to 300 , and the PON:POP ratio increased to a range of 30 to 50 . 
At an offshore station in the Baltic proper, Larsson et al. (2001) measured an increase in the C:P elemental ratio of Aphanizomenon filaments of from about 30 after the phytoplankton spring bloom in May to 420 in August during the peak of the biomass (an increase by a factor of 13), and a corresponding N:P ratio increase from 6.5 to 65 (factor of 10). The authors argued that the phosphorus needed for the build-up of Aphanizomenon biomass was nearly equal to the intracellular storage before the biomass increase, and that the population developed a progressive $\mathrm{P}$ deficiency, with growth rate decreasing to near zero at the biomass peak (Larsson et al. 2001).

Unlike Aphanizomenon, Nodularia seems to lack the capacity to grow extensively on internal $P$ reserves and must obtain dissolved inorganic phosphorus (DIP) from external sources (Larsson et al. 2001). Both Nodularia and Anabaena spp. are reported to have generally higher affinity for P than Aphanizomenon (DeNobel et al. 1997). This fits the different biomass response patterns of the $\mathrm{N}_{2}$-fixing cyanobacteria in our experiments.

We hypothesise that the biomass increase of Aphanizomenon in the mesocosms without $\mathrm{P}$ addition was largely based on internal cellular $\mathrm{P}$ storage, derived from the initial situation ( $\mathrm{C}$ unit), or, at the latest, from the boosting period ( $\mathrm{N}, 5 \mathrm{~N}, 5 \mathrm{NG}$ units). The increasing POC:POP and PON:POP ratios in these mesocosms suggested progressive P limitation at the bulk level, but the biomass increase of Aphanizomenon continued to increase, suggesting that the growth rate was controlled by other factors than nutrient limitation, e.g. temperature. However, we speculate that, if the experiment had been prolonged, the growth rate of Aphanizomenon would have decreased once the internal C:P and N:P ratios had reached the critical values of about 420 and 65, respectively (Larsson et al. 2001).

In contrast, Nodularia and Anabaena spp. responded with significantly lower biomass accumulation in the mesocosms with no continuous phosphate supply. Phosphorus limitation of $A$. lemmermannii, the dominant Anabaena species in the mesocosms, was revealed not only by lower biomass, but also as a significantly increased akinete production rate (Olli et al. 2005). This would imply that Nodularia and Anabaena spp. rely mostly on external P sources. These sources could be either inorganic P surplus, or immediate bacterial release of inorganic $\mathrm{P}$ from dissolved organic sources (Tamminen 1989). In the low-P conditions of the offshore Baltic Sea in summer, the high success of Nodularia could therefore be dependent on maintaining an active microbial loop within the aggregates typical for these species.

Our results indicate large species-specific differences in phosphorus metabolism among the filamentous cyanobacteria in the Baltic Sea, and flexible intra- cellular phosphorus management in Aphanizomenon sp., supporting previous monitoring evidence from blooms in the Baltic proper (Larsson et al. 2001). It is therefore evident that there is not a uniform 'Baltic Sea cyanobacterial problem', with a single and simple management solution, but instead several speciesspecific cyanobacterial strategies to compete with coexisting cyanobacterial and other phytoplankton species. The dominant $\mathrm{N}_{2}$-fixing cyanobacteria differ in their $\mathrm{P}$ demands, and several bloom forming cyanobacteria in coastal areas of the Baltic Sea (e.g. the potentially toxic Microcystis aeruginosa, Planktothrix agardhii; Finni et al. 2001) are not known to fix $\mathrm{N}_{2}$. The high flexibility of particulate nutrient ratios of, especially, Aphanizomenon sp. during bloom development (Larsson et al. 2001, present study) cast doubt on the management applicability of Baltic Sea models (e.g. Kiirikki et al. 2001) based on fixed (Redfield) stoichiometry of different primary producers ('nitrogenfixers' and 'others'), following the 1-dimensional ocean model of Tyrrell (1999).

\section{Other causes for cyanobacterial success}

The success of the filamentous cyanobacteria cannot be explained by nutrient availability alone. In 3 earlier experiments with these mesocosms (each with a different experimental design) at the same location and during the same season, we observed explosive development of fast-growing opportunistic flagellates (Olli et al. 1996, Olli \& Seppälä 2001). It is obviously difficult to predict, which phytoplankton group will be most favoured by the new conditions in the mesocosms. We believe that the high initial mesozooplankton biomass (exceeding the phytoplankton biomass on average by a factor of 2.8) in this experiment controlled the biomass of other phytoplankton species, especially flagellates in the edible size class $(<30 \mu \mathrm{m})$ and therefore benefited the generally less edible cyanobacteria (Sellner et al. 1996).

Second, cyanobacteria are favoured by elevated temperatures (Plinski \& Józwiak 1999). The optima of the 2 main bloom-forming cyanobacteria in the Baltic differ, being lower $\left(>16^{\circ} \mathrm{C}\right)$ for Aphanizomenon sp. than for Nodularia spumigena $\left(>20^{\circ} \mathrm{C}\right)$ (Plinski \& Józwiak 1999). The temperature dependence fits the consistent biomass increase of Aphanizomenon and the late appearance of $N$. spumigena during the exceptionally warm final period (up to $22^{\circ} \mathrm{C}$ ) of the experiment.

However, temperature and zooplankton could not have caused the observed differences in phytoplankton community structure between the $\mathrm{N}$ - and $\mathrm{P}$ enriched mesocosms. Due to heat exchange, water temperature inside and outside the mesocosms was in 
close proximity, and there were no temperature differences between the treatments. Zooplankton composition and biomass were also very similar between the treatments. Furthermore, due to the transparent walls, the light climate within the mesocosms depends more on the turbidity of the outside water than on the extent of the algal bloom inside (Olli \& Seppälä 2001). Thus, we are left with the conclusion that the observed differences in biomass responses of different cyanobacterial species were due to limitation by different macronutrients, although the high grazing pressure on competing algae, and the high temperatures towards the end of the experiment, provided exceptionally favourable conditions for cyanobacteria in general.

\section{The effect of scales on observed cyanobacterial limitation patterns}

Conclusions similar to ours can be deduced from several other investigations, though, at different temporal and spatial scales. In a smaller-scale mesocosm experiment $\left(0.3 \mathrm{~m}^{3}\right.$ units; $\mathrm{N}, \mathrm{P}$ and Fe addition) with a natural plankton community in a semi-enclosed bay of the western Baltic Sea, Rydin et al. (2002) observed a pronounced $\mathrm{N}_{2}$-fixing cyanobacterial bloom (Aphanizomenon sp. and Anabaena sp.) after P addition, while non- $\mathrm{N}_{2}$-fixing cyanobacteria and eukaryotes increased and depressed the development of $\mathrm{N}_{2}$-fixing cyanobacteria in mesocosms with combined $\mathrm{N}$ and $\mathrm{P}$ addition (Redfield ratio). However, in contrast to our study, mesocosms without $\mathrm{P}$ addition (control, $\mathrm{N}, \mathrm{Fe}+\mathrm{N}$ ) revealed no biomass response during the $25 \mathrm{~d}$ duration of the experiment (Rydin et al. 2002); the experimental design of Rydin et al. did not include a boosting period. The phytoplankton community enclosed in the bags in mid-July was already P starved, as indicated by undetectable phosphate concentration in the ambient water (Rydin et al. 2002). This would imply low cellular P reserves of Aphanizomenon from the start, and explains its lack of growth in P-limited units.

On a whole bay scale our conclusions are supported by the Himmerfjärden eutrophication study (Elmgren \& Larsson 2001a). Himmerfjärden is an eutrophic Swedish bay in the north-western Baltic Sea, south of Stockholm. Advanced $90 \% \mathrm{~N}$ reduction in the sewage treatment plant shifted the previously P-limited Himmerfjärden Bay to an N-limited coastal area, with markedly reduced chl $a$ and phytoplankton biomass in spring, summer and as an annual average, but it induced the re-appearance of $\mathrm{N}_{2}$-fixing cyanobacteria blooms in the bay system (Elmgren \& Larsson 2001a). These cyanobacteria were P limited, but less severely so than in the open Baltic, with nitrogen isotope ratios indicating almost complete dependency on fixed nitro- gen. After a politically and legally difficult decision, more $\mathrm{N}$ was released into the bay when the risk of a $\mathrm{N}_{2}$-fixing cyanobacterial bloom was considered evident in May 2001. The following summer bloom remained below the level experienced in 2000 (Elmgren \& Larsson 2001b).

The ecosystem-level temporal and spatial scales covered by the Himmerfjärden monitoring study (Elmgren \& Larsson 2001a) lend unique credibility to its results. Nevertheless, experimental control of open systems is necessarily weak, with no strict possibilities to distinguish between the relative roles of interannual and seasonal variability, and temporally (annually) changing treatments. This stresses the need for supplementary evidence provided by controlled short-term enclosure experiments on the causalities between the nutrient availability experienced by plankton and their species-specific and intra-assemblage responses.

Several cruise studies on cyanobacterial bloom development in the Baltic Sea have suggested different niches for the 2 offshore-blooming filamentous species Nodularia spumigena and Aphanizomenon sp. (e.g. Niemisto et al. 1989, Kononen et al. 1996, Kanoshina et al. 2003, Vahtera et al. 2005). These niches have usually been explained by the different temperature optima, as well as the observed differences of the vertical positioning of the 2 species. Aphanizomenon is frequently found relatively evenly distributed in the mixed surface layer prior to the actual bloom peak, whereas Nodularia appears to depend on a relatively stagnant water column and accumulation in the highirradiance, warm surface layer, in order to reach bloom densities.

Previously Niemisto et al. (1989) suggested that the different vertical positioning of Aphanizomenon and Nodularia allows their coexistence and prevents competition for phosphorus between these algae. Accordingly, our experimental data, with a strong increase of POC:POP during cyanobacterial development, suggest that Aphanizomenon could accumulate sufficient $\mathrm{P}$ for bloom biomasses from nutrient-replete thermocline waters; subsequently it could, by being able to control its buoyancy, ascend to P-depleted surface layer to harvest solar energy for $\mathrm{N}_{2}$ fixation.

After upwelling events, the $\mathrm{N}_{2}$-fixer blooms have been found to utilise the P supply to the surface layer, with a time lag (Kononen et al. 1996, Vahtera et al. 2005). Interestingly, the observed temporal development of these post-upwelling blooms (2 to $3 \mathrm{wk}_{\text {; }}$ Vahtera et al. 2005) corresponds well to our experimental data. With their slow growth and nutrient uptake rates compared to other summertime phytoplankton, the filamentous cyanobacteria obviously need either tight grazer control of the competitors, or very low N:P availability to prevent competitors from 
taking advantage of the episodic $\mathrm{P}$ input, to be able to utilise these upwelling pulses.

Finally, a noteworthy relationship between the extent of Nodularia spumigena blooms and N:P ratio on a basin-wide scale was highlighted by Kahru et al. (2000). Between 1982 and 1994 extensive cyanobacterial accumulations were restricted to the waters west of the quasi-stationary frontal system at ca. $24^{\circ} 30^{\prime} \mathrm{E}$ in the western GOF, but were not recorded in the more eutrophic central and eastern parts of the GOF. For the latter half of the 1990s, massive surface accumulations of $N$. spumigena occurred throughout the whole GOF, including the eastern portion. This emergence of blooms was attributed to the increase in the phosphate concentration and a corresponding decrease in the N:P ratio, most marked in the eastern part of the GOF, caused by the inflow of saline water into the Baltic Sea in 1993, which pushed the low-oxygen deep water of the Baltic proper into the GOF (Kahru et al. 2000).

Although anthropogenic inputs of phosphorus into the GOF have decreased since the 1980s, the reserves in the bottom sediments are high (Lehtoranta et al. 1997). Oxygen deficiency in deep water leads to mass release of phosphorus stored in oxic sediments and stimulates denitrification, causing decreased N:P supply ratio to the productive layer. This demonstrates that it is not the direct anthropogenic discharge per se, but the supply rate of $\mathrm{N}$ versus $\mathrm{P}$ to the euphotic layer through biogeochemical ecosystem cycles that governs the short-term competitive ability of $\mathrm{N}_{2}$-fixing cyanobacteria in the Baltic Sea.

\section{Cyanobacteria and eutrophication management in the Baltic Sea}

These results have implications on coastal eutrophication management and decision-making in the Baltic Sea catchment area. Huge late-summer surface accumulations of filamentous cyanobacteria (Kahru et al. 1994, 2000) have aroused considerable public concern, especially as several of the common Baltic Sea species (Nodularia, Anabaena, Microcystis) are toxic (Willén \& Mattsson 1997, Luckas et al. 2005). Based on the $\mathrm{N}_{2}$ fixing capacity of several species, effective P-discharge reductions have been advocated to control the offshore blooms, at the expense of $\mathrm{N}$ reductions. The latter have been suggested to be risky, possibly leading to increasing cyanobacterial blooms. In recent environmental debate, this reasoning has, at times, been pushed even further, demanding increases of $\mathrm{N}$ loading to manage toxic blooms.

Our results showed that moderate, and even excessive $\mathrm{N}$ additions (high to very high DIN:DIP ratios), rather specifically lowered the competitive ability of some cyanobacteria, e.g. Anabaena spp., but generally failed to prevent $\mathrm{N}_{2}$-fixing cyanobacterial blooms once the conditions were otherwise favourable (and/or unfavourable to competing algae). This underlines the multidimensionality of controlling mechanisms for blooms, and cautions against straightforward loadresponse management conclusions based on $\mathrm{N}_{2}$-fixing cyanobacterial species considered in isolation from the ecosystem context.

It can be debated whether the $\mathrm{N}_{2}$-fixation rate is high enough to compensate for the 'proximate' shortage of inorganic nitrogen in the Baltic Sea, leading to 'ultimate' phosphorus limitation along the lines of the 1dimensional model suggested for the World Ocean by Tyrrell (1999). The evidence from our short-term experiment revealed that the accumulation of total organic $\mathrm{N}$ in the $\mathrm{P}, 5 \mathrm{P}$ and $5 \mathrm{PG}$ enclosures was on average 80 to $90 \%$ of the corresponding rates in the N, $5 \mathrm{~N}$ and $5 \mathrm{NG}$ enclosures after the boosting period, with the difference disappearing by the end of the experiment. This indicates that in the time frame of our highly cyanobacteria-dominated mesocosms, $\mathrm{N}_{2}$ fixation did compensate for the lack of bound $\mathrm{N}$ supply rates.

The spatial and temporal realities of the temperate Baltic Sea ecosystem cast, however, serious doubt on the applicability of the simplistic homogenous culture analogy at larger scales. The large total nutrient load entering the Baltic Sea, with the high N:P ratio of the Baltic Sea (ca. 3-fold the Redfield ratio; Stålnacke et al. 1999), is only partly bioavailable, and, especially, the share of recalcitrant DON is very high (70 to $90 \%$; Jørgensen et al. 1999). Moreover, the nutrient inputs are strongly modified by biological processes in near-coast systems (Pitkänen \& Tamminen 1995), further undermining the traditional engineering approach. Controlling the most conspicuous, offshore Nodularia blooms by fine-tuning coastal discharges is especially problematic. Before the coastal nutrient discharges reach the offshore July/August ecosystem, the anthropogenic nutrient supply has passed through different seasons in the N-limited coastal regimes, where eutrophication is primarily driven by $\mathrm{N}$ availability, and where also nonheterocystous cyanobacteria like Microcystis and Pseudanabaena benefit from dissolved N.

The spatially extended Nodularia blooms into the GOF during the last $10 \mathrm{yr}$ seem to be connected to increased bottom water anoxia and subsequent $\mathrm{P}$ release from sediments, due to extension of the halocline into the GOF (Kahru et al. 2000). Increasing $N$ inputs to the coastal areas affect the system in much the same way, and enhance the effects of physical stagnation. Spring-bloom sedimentation is the main organic matter supply (Heiskanen 1998) consuming bottom water oxygen, and the bloom magnitude is $\mathrm{N}$ limited. Increased $\mathrm{N}$ discharges would therefore 
increase dissolved P supply to the system via 'internal loading' and, consequently, promote offshore $\mathrm{N}_{2}$-fixing blooms. It is evident that such feedback processes within the system will make the outcome of any narrowly targeted bloom control strategy increasingly uncertain with increasing distance from coastal nutrient sources. Paradoxically, when targeting cyanobacterial bloom reduction over more than a single season, $\mathrm{N}$ discharges also need to be lowered, in order to control for internal P supply. Overall decrease of both $\mathrm{N}$ and $\mathrm{P}$ pools in the system by significant loading reductions appears to be the only feasible management strategy to reduce cyanobacterial and other environmental problems connected to eutrophication of the Baltic Sea.

Acknowledgements. This research was supported by the European Commission through the Projects DANLIM (EVK3CT-2001-00049) and THRESHOLDS (GOCE-003900), and the Estonian Science Foundation (ETF 5262). The authors are thankful to the whole DANLIM team for cooperation during the mesocosm experiment, especially to J. Seppälä for the chlorophyll data. We also thank A. Põllumäe for zooplankton data, E. Salminen and M. Sjöblom for nutrient analyses, and the staff of the Tvärminne Zoological Station for their help and hospitality. The comments of 3 anonymous reviewers improved the original manuscript.

\section{LITERATURE CITED}

DeNobel WT, Huisman J, Snoep JL, Mur LR (1997) Competition for phosphorus between the nitrogen-fixing cyanobacteria Anabaena and Aphanizomenon. FEMS Microbiol Ecol 24:259-267

Elmgren R (2001) Understanding human impact on the Baltic ecosystem: changing views in recent decades. Ambio 30: 222-231

Elmgren R, Larsson U (2001a) Eutrophication in the Baltic Sea area: integrated coastal management issues. In: Von Bodungen B, Turner RK (eds) Science and integrated coastal management. Dahlem University Press, Berlin, p 15-35

Elmgren R, Larsson U (2001b) Nitrogen and the Baltic Sea: managing nitrogen in relation to phosphorus. Sci World 1: 371-377

Ferber LR, Levine SN, Lini A, Livingston GP (2004) Do cyanobacteria dominate in eutrophic lakes because they fix atmospheric nitrogen? Freshw Biol 49:690-708

Finni T, Kononen K, Olsonen R, Wallström K (2001) The history of cyanobacterial blooms in the Baltic Sea. Ambio 30: 172-178

Granéli E, Wahlström K, Larsson U, Granéli W, Elmgren R (1990) Nutrient limitation and primary production in the Baltic Sea area. Ambio 19:142-151

Grasshoff K, Ehrhardt M, Kremling K (1983) Methods of seawater analysis. Verlag Chemie, Weinheim

Heiskanen AS (1998) Factors governing sedimentation and pelagic nutrient cycles in the northern Baltic Sea. PhD dissertation, Helsinki University

Jørgensen NOG, Tranvik LJ, Berg GM (1999) Occurrence and bacterial cycling of dissolved nitrogen in the Gulf of Riga, the Baltic Sea. Mar Ecol Prog Ser 191:1-18
Kahru M, Horstmann U, Rud O (1994) Satellite detection of increased cyanobacteria blooms in the Baltic Sea: Natural fluctuations or ecosystem change? Ambio 23:469-472

Kahru M, Leppänen JM, Rud O, Savchuk OP (2000) Cyanobacteria blooms in the Gulf of Finland triggered by saltwater inflow into the Baltic Sea. Mar Ecol Prog Ser 207: $13-18$

Kanoshina I, Lips U, Leppänen JM (2003) The influence of weather conditions (temperature and wind) on cyanobacterial bloom development in the Gulf of Finland (Baltic Sea). Harmful Algae 2:29-41

Kiirikki M, Inkala A, Kuosa $H$, Pitkänen $H$, Kuusisto $M$, Sarkkula J (2001) Evaluating the effects of nutrient load reductions on the biomass of toxic nitrogen-fixing cyanobacteria in the Gulf of Finland, Baltic Sea. Boreal Environ Res 6:131-146

Kivi K, Kaitala S, Kuosa H, Kuparinen J, Leskinen E, Lignell R, Marcussen B, Tamminen T (1993) Nutrient limitation and grazing control of the Baltic plankton community during annual succession. Limnol Oceanogr 38:893-905

Kononen K, Kuparinen J, Mäkelä K, Laanemets J, Pavelson J, Nõmmann S (1996) Initiation of cyanobacterial blooms in a frontal region at the entrance to the Gulf of Finland, Baltic Sea. Limnol Oceanogr 41:98-112

Kuuppo-Leinikki P, Autio R, Hällfors S, Kuosa H, Kuparinen J, Pajuniemi R (1994) Trophic interactions and carbon flow between picoplankton and protozoa in pelagic enclosures manipulated with nutrients and a top predator. Mar Ecol Prog Ser 107:89-102

Laamanen MJ, Forsström L, Sivonen K (2002) Diversity of Aphanizomenon flos-aquae (Cyanobacterium) populations along a Baltic Sea salinity gradient. Appl Environ Microbiol 68:5296-5303

Larsson U, Elmgren R, Wulff F (1985) Eutrophication and the Baltic Sea: causes and consequences. Ambio 14:9-14

Larsson U, Hajdu S, Walve J, Elmgren R (2001) Baltic Sea nitrogen fixation estimated from the summer increase in upper mixed layer total nitrogen. Limnol Oceanogr 46: 811-820

Lehtimäki J, Moisander P, Sivonen K, Kononen K (1997) Growth, nitrogen fixation, and nodularin production by two Baltic Sea cyanobacteria. Appl Environ Microbiol 63: $1647-1656$

Lehtoranta J, Pitkänen H, Sandman O (1997) Sediment accumulation of nutrients (N, P) in the eastern Gulf of Finland (Baltic Sea). Water Air Soil Pollut 99:477-486

Lignell R, Lindqvist K (1992) Effect of nutrient enrichment and temperature on intracellular partitioning of ${ }^{14} \mathrm{CO}_{2}$ in a summer phytoplankton community in the northern Baltic. Mar Ecol Prog Ser 86:273-281

Lignell R, Seppälä J, Kuuppo P, Tamminen T, Andersen T, Gismervik I (2003) Beyond bulk properties: responses of coastal plankton communities to nutrient enrichment in the northern Baltic Sea. Limnol Oceanogr 48:189-209

Luckas B, Dahlmann J, Erler K, Gerdts G, Wasmund N, Hummert C, Hansen PD (2005) Overview of the phytoplankton toxins and their recent occurrence in the North and Baltic Seas. Environ Toxicol 20:1-17

Niemisto L, Rinne I, Melvasalo T, Niemi Å (1989) Blue-green algae and their nitrogen fixation in the Baltic Sea in 1980, 1982 and 1984. Meri 17:1-59

Olli K (2004) Temporary cyst formation of Heterocapsa triquetra (Dinophyceae) in natural populations. Mar Biol 145:1-8

Olli K, Seppälä J (2001) Vertical niche separation of phytoplankton: large-scale mesocosm experiments. Mar Ecol Prog Ser 217:219-233 
Olli K, Heiskanen AS, Seppälä J (1996) Development and fate of Eutreptialla gymnastica bloom in nutrient enriched enclosures in the coastal Baltic Sea. J Plankton Res 18: $1587-1604$

Olli K, Kangro K, Kabel M (2005) Akinete production of Anabaena lemmermannii and A. cylindrica (Cyanophyceae) in natural populations of $\mathrm{N}$ - and P-limited coastal mesocosms. J Phycol 41:1094-1098

Pitkänen H, Tamminen T (1995) Nitrogen and phosphorus as production limiting factors in the estuarine waters of the eastern Gulf of Finland. Mar Ecol Prog Ser 129:283-294

Pitkänen H, Lehtoranta J, Raike A (2001) The internal nutrient fluxes counteract decreases in external load: the case of the estuarial eastern Gulf of Finland, Baltic Sea. Ambio 30:195-201

Pitkänen H, Lehtoranta J, Peltonen H, Laine A and 7 others (2003) Benthic release of phosphorus and its relation to environmental conditions in the estuarial Gulf of Finland, Baltic Sea, in the early 2000s. Proc Est Acad Sci Biol Ecol 52:173-192

Plinski M, Józwiak T (1999) Temperature and N:P ratio as factors causing blooms of blue-green algae in the Gulf of Gdansk. Oceanologia 41:73-80

Raateoja M, Seppälä J, Kuosa H, Myberg K (2005) Recent changes in trophic state of the Baltic Sea along SE coast of Finland. Ambio 34:188-191

Rönner U (1985) Nitrogen transformations in the Baltic proper: denitrification counteracts eutrophication. Ambio 14:134-138

Rydin E, Hyenstrand P, Gunnerhed M, Blomqvist P (2002) Nutrient limitation of cyanobacterial blooms: an enclosure experiment from the coastal zone of the NW Baltic proper. Mar Ecol Prog Ser 239:31-36

Editorial responsibility: Howard Browman (Associate Editorin-Chief), Storebø, Norway
Sellner KG, Olson MM, Olli K (1996) Copepod interactions with toxic and non-toxic cyanobacteria from the Gulf of Finland. Phycologia 35:177-182

Seppälä J, Tamminen T, Kaitala S (1999) Experimental evaluation of nutrient limitation of phytoplankton in the Gulf of Riga. J Mar Syst 23:107-126

Solorzano L, Sharp JH (1980) Determination of total dissolved phosphorus and particulate phosphorus in natural waters. Limnol Oceanogr 25:754-758

Stålnacke P, Grimvall A, Sundblad K, Tonderski A (1999) Estimation of riverine loads of nitrogen and phosphorus to the Baltic Sea, 1970-1993. Environ Monit Assess 58:173-200

Tamminen T (1989) Dissolved organic phosphorus regeneration by bacterioplankton: 5 '-nucleotidase activity and subsequent phosphate uptake in a mesocosm enrichment experiment. Mar Ecol Prog Ser 58:89-100

Tuominen L, Heinänen A, Kuparinen J, Nielsen LP (1998) Spatial and temporal variability of denitrification in the sediments of the northern Baltic Proper. Mar Ecol Prog Ser 172:13-24

Tyrrell T (1999) The relative influence of nitrogen and phosphorus on oceanic primary production. Nature 6744:525-531

Vahtera E, Laanemets J, Pavelson J, Huttunen M, Kononen K (2005) Effect of upwelling on the pelagic environment and bloom-forming cyanobacteria in the western Gulf of Finland, Baltic Sea. J Mar Syst 58:67-82

Wasmund N, Voss M, Lochte K (2001) Evidence of nitrogen fixation by non-heterocystous cyanobacteria in the Baltic Sea and re-calculation of a budget of nitrogen fixation. Mar Ecol Prog Ser 214:1-14

Willén T, Mattsson R (1997) Water-blooming and toxin-producing cyanobacteria in Swedish fresh and brackish waters, 1981-1995. Hydrobiologia 353:181-192

Submitted: April 10, 2006; Accepted: July 17, 2006

Proofs received from author(s): February 7, 2007 